\title{
When Ludruk Meets Wayang: Development of A Competition-Based Learning System Between Javanese Language Classes at SMKN 3 Malang
}

\author{
Astrid Wangsagirindra Pudjastawa ${ }^{1}$, Varary Mechwafanitiara Cantika ${ }^{2}$ \\ Javanese Language Education of Graduate School, State University of Yogyakarta ${ }^{1}$, Javanese \\ Language Education, State University of Surakarta ${ }^{2}$ \\ \{a.w.pudjastawa@gmail.com\}
}

\begin{abstract}
The development of local culture-based learning is needed to support meaningful learning. Festival or competition-based learning systems are expected to increase the frequency of the learning process, enrich learning materials, and create a flexible and fun learning environment. The purpose of this study was to determine the implementation of festival-based learning in Javanese language subjects at SMK Negeri 3 Malang. The type of research applied is research and development. This research consists of three stages, namely a conceptual model, a hypothetical model, and an empirical model. The hypothetical model was tested on a small group scale to obtain an empirical model and an empirical model was tested in the field to obtain a festival-based learning model. The results showed that competition-based learning was considered good. This can be seen from several aspects of whether or not it is applied in SMK N 3 Malang, its application is a fun learning model, both in terms of readiness and supporting factors. competition-based learning can be recommended as a local culture-based learning model equipped with guided outreach and training.
\end{abstract}

Keywords: Competition based learning, wayang, ludruk, javanese language

\section{Introduction}

Based on the Regulation of the Minister of Education and Culture Number 20 of 2016 concerning competency standards for primary and secondary education graduates, it is hoped that students will have factual, conceptual, procedural, and metacognitive knowledge on a technical, specific, detailed, and complex level. where students are able to link knowledge in everyday life with the hope that students will be able to solve problems later. Many experiences are needed by students to gain the ability to solve a problem that will be faced in their future lives.

Students in the learning process are expected to be able to play an active role, have the ability to communicate, solve problems, and apply learning in everyday life. The benefits that will be obtained by students through problem-solving include students learning more actively in the learning process [1]. 
One of the things that can shape student character in order to solve all problems in life is Character Education. Character education plays a role in supporting educational goals, namely helping individuals become knowledgeable and helping individuals to become good personalities for themselves and the surrounding community. [2].

Based on this belief, educational institutions in the early days handled character education directly through disciplinary action, teachers as role models, and daily curricula. Character education can enter the deepest space of an individual's personality combined through other disciplines, including children practicing reading or arithmetic and learning lessons about honesty, love for others, kindness to living beings, hard work, frugality, patriotism, and courage; which is commonly referred to as interdisciplinary flexibility [3].

Art is a discipline that has the flexibility to collaborate with other disciplines in an interdisciplinary arena [4]. Interdisciplinary art education is a part of integrated learning with other fields to achieve educational goals, increase knowledge, provide understanding, and the emergence of new studies and sciences [5]. The purpose of character education through art is part of achieving educational goals [6]. Art is a tool to achieve educational goals that do not require individuals to become artists but rather focus on the process [7]. In the process of education through art, individuals can develop through various processes of aesthetic experiences [8]. Furthermore, through art, individuals are taught to gain real experience in understanding traditional arts in Indonesia. Through this real experience, it is hoped that they can develop their potential. Art as the basis of education was expressed by Plato who stated that "art should be the basis of education" [9].

At present, the traditional performing arts in schools seem to be the biggest new culture that is considered modern. In the end, modern culture is what makes mass culture representation of the times. Of course, something that has become a consumer of society is very thick by including school children as their new culture. Mass culture is a dynamic and revolutionary force, which has broken down class boundaries, traditions, tastes, and dissolved all cultural differences. [10].

For this reason, it is necessary to build traditional performing arts in schools so that students can get to know their own culture. Students are given space to understand how traditional performing arts have interesting forms and meanings. Through this, it is hoped that students will try to get to know more and try to always love. Traditional art is a product that has an important meaning for the learning of the current generation. Thus they will understand the work produced by their predecessors. Works that are born from various entities that become identities, namely Indonesia.

One of the model approaches is to combine the elements of wayang and ludruk as the basis for the type of performance to be used for competition media. During this period, the puppeteer and ludruk artists experienced a decline in dalang job acceptance. If you take a closer look, only professional artists with reputations have survived to this day. Moreover, the lower-level artists began to not respond. The turning point of the wayang and ludruk explosion resulted in a decline in the public interest, especially the younger generation, towards wayang and ludruk. Also, several genres of wayang are experiencing extinction that can threaten the life of Indonesian wayang.

From the external side, artists are faced with technological advances in today's digital era. There are at least three things that become obstacles to the continuation of the art of wayang and ludruk today, namely: the decline in the interest of the younger generation, wayang and ludruk are threatened with extinction and the phenomenon of the digital era. This raises the awareness to create wayang and ludruk performances from a contemporary perspective. This means that the puppet show innovation is carried out in line with the industrial era 4.0. 
Based on the above thought, the researcher took the research title "When Ludruk Meets Wayang: Development of a Learning System Based on Inter-Class Competition in Javanese Language Learning at SMK Negeri 3 Malang.

\section{Research Methods}

This study uses research and development research. In this study, the type of data presented is qualitative data obtained empirically from respondents in the field regarding the learning system developed based on competition between ludruk puppet classes. The research subjects in the development of a competition-based learning system between the puppet ludruk classes were students of SMK Negeri 3 Malang.

The focus of this research is on how to apply traditional art-based learning as an alternative learning model in Javanese language subjects at SMK Negeri 3 Malang. Data collection methods used in this study were observation, questionnaire techniques, and interviews. While the data analysis stage is carried out through data collection, data reduction, data presentation, and decision making or verification. In this study, the authors used the development model described by Plomp [11].

The design of the Plomp model development research in this study is explained as follows.

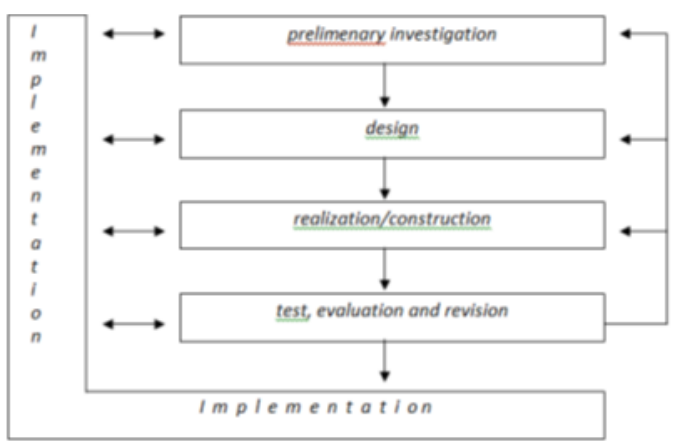

Fig 1. Plomp Development Model

\section{Results and Discussion}

\section{Prototyping Stage of Wayang Ludruk Show}

This section contains an explanation of the procedures carried out in the process of making the ludruk wayang performance art. Composing new performing arts is one of the means or ways for artists to produce art products. Every artist has their way or way of arranging works according to their habits [12]. The stage of making a wayang ludruk prototype is a. Choosing materials, b. Processing materials, c. Packaging Materials, d. Presenting material as a learning medium.

\section{Choosing materials}

This section is the stage where the selection of materials or the selection of materials used to create a genre of performance. Determine the material related to the selection of puppet 
material, the music genre taught, what concepts are taught, the script model, the source of the story. Choosing materials is the responsibility of the first writer, Astrid Wangsagirindra Pudjastawa. In selecting materials, the writer enriches and seeks inspiration by visiting ludruk and wayang artists.

\section{Processing materials}

This stage is the stage where the ingredients will be mixed into a product as a guide for students in producing wayang ludruk shows. The processing stage is an experimental area as well as a laboratory. The processed material is a technical guideline for wayang ludruk shows.

\section{Packaging materials}

Packaging materials are an in-depth study activity or some sort of trial and error stage. The purpose of this activity is to review the technical guidelines and teaching materials that will be applied.

\section{Presenting material as a learning medium.}

Presentation of material is an activity in learning starting from forming wayang ludruk performance committees, selecting class structures, and scheduling activities that students must do starting from the digestive stage to then displaying wayang ludruk shows or expressing works of art that have been compiled.

\section{Concept of Wayang Ludruk Show}

The ludruk wayang performance model is one form of innovation in wayang performances by combining it with ludruk performances to create a genre of performance that is flexible and financially inexpensive so that it can be applied in the school environment. A classical shadow puppet show with several elements, among others: stage (puppeteer, pengrawit, pesinden, penggerong, and stage); performance equipment (puppets, screens, kothak, cempala, keprak, gamelan, lights, and loudspeakers); And the elements of the work in the show (play, sabetan, antawecana, and pakeliran) are packaged by applying renewable technology, besides the wayang is returned to its inward form, which is an image-based performance. Wayang performance as the main material is packaged with a new approach. Therefore, other materials (stock shoot) are needed, such as forests, waves, oceans, sky, rain, sun, animals, etc., combined with the puppet show. [13].

The ludruk wayang performance model is based on the concept of the form of the show, the concept of play, the concept of sabetan, the concept of music, and the concept of narrative. This concept is interrelated in forming a unified model of ludruk wayang performances. The concept of the ludruk wayang performance form has the following indications: (1) a combination of the shadow puppet performance art and the ludruk art discipline; (2) there was a move from ludruk to wayang golek; (3) creators and innovators who are competent in understanding wayang and ludruk plays; and (4) the form of ludruk puppet shows taking into account the segmentation of society.

The creations and innovations of ludruk puppet shows are exposed to segments of society. The public's response to the quality of the show is an important input for the artist. The ludruk puppet show is prepared to foster the interest of the younger generation in wayang, so that the youth audience segment becomes an orientation. Besides, the era of the industrial revolution 4.0 needs to be addressed with innovative wayang golek performances that can be enjoyed en masse, both through screenings in theaters and via the internet. The concept of the wayang ludruk play, like traditional theater in general, refers to the structure of the drama, namely plot, 
characterization, setting, theme, and message. [14]. Here the relationship between plot, characterization, setting, theme, and message forms a dramatic structure. The presence of a line of play including characterization, settings, and message themes. The concept of the wayang ludruk play is: (1) having a level of flow, starting from the stage of introduction, climax, to completion; (2) dominantly uses the causality pathway; and (3) carry out the creation of a clear plot, events that run simultaneously and are connected in a single unit, or say a complex plot.

\section{Aspect Assessment of Wayang Ludruk Performance}

The assessment of student respondents was obtained from filling out the questionnaire after the trial process was carried out. This product assessment is seen in various aspects.

a. In its application as a fun learning method, it is obtained data that $100 \%$ of respondents rated the learning method as fun.

b. In terms of the availability of supporting facilities and mentoring during the learning process, $86 \%$ of respondents rated the teacher as providing assistance well. The reason is that the teacher schedules the exercises well and is always there in the learning process to help students in the process of making puppets and music to accompany the performance. Meanwhile, $14 \%$ considered it less because they did not understand the concept of the show and the material provided was still limited.

Examiners provide input so that the genre of the story must be guarded so that students present performances according to their age. Apart from input on the genre of the story, there is no more input or criticism, in general, it is good.

Prospects and Implementation of Inter-Class Competition Based Learning Systems in Javanese Language Learning at SMK Negeri 3 Malang Wayang Ludruk

a. Judging from whether or not an inter-class competition-based learning system is applied at SMK Negeri 3 Malang, $80 \%$ of respondents stated that it is very suitable to be applied at SMK Negeri 3 Malang. This answer is supported by various logical reasons, including because students are actively involved and students at SMK are burdened with too much draining and mindful material. So it is necessary to have a fun learning system as a means of brainstorming students. $20 \%$ of all respondents stated that this learning system was not suitable to be applied at SMK Negeri 3 Malang because students sometimes took advantage of learning outside the Javanese language for practice.

b. In terms of preparation and supporting factors for implementing the learning system at SMK Negeri 3 Malang, various inputs are needed. The Flipped Classroom-based learning system can shorten the training process carried out by students and reduce students who use school hours other than Javanese lessons to practice preparation for ludruk puppet shows.

\section{Model of the Wayang Ludruk Performance: A Forum for Learning Development Based on Regional Traditional Arts}

Wayang performances contain high-quality values because they reveal the noble values of the Indonesian people. Therefore, the innovation of ludruk wayang performances still rests on the real value, namely the spirit that lives the wayang. The value of human life is transformed in the wayang play into character learning and manners. In this case, wayang raises universal human values so that it becomes a reference for cultured human behavior patterns. The values inherent in wayang, namely religious values, ethical values, and aesthetic values, are ideally recognized as a reference for the actions of the Indonesian people [13].

Various forms of Indonesian wayang development aim to increase the interest of the younger generation in wayang and efforts to maintain its existence. The development of wayang 
is also related to cultural progress that has been disseminated by the state. Law Number 5 of 2017 concerning the Advancement of Culture provides space and legal guarantees for the implementation of efforts to advance cultural arts. Cultural development includes the protection, development, utilization, and fostering of culture. In cultural development, there are efforts to revive the cultural ecosystem and improve, enrich, and disseminate culture. The methods used are dissemination, assessment, and diversity enrichment.

The development of the shadow puppet art form includes various models, namely: (1) the verbal discourse model of puppetry; (2) wayang visual graphic model; and (3) an auditive visual model of wayang [13]. The first model is oriented towards writing about wayang which can be easily accessed by the wider community. The second model can be done in the form of a graphic visual model, which is a more dominant model with a visual display or a puppet image. The third model is the development of wayang that is centered on the audiovisual display. This model is considered more complex and interesting because it fulfills the visual (visual) and auditory (audio or sound) aspects.

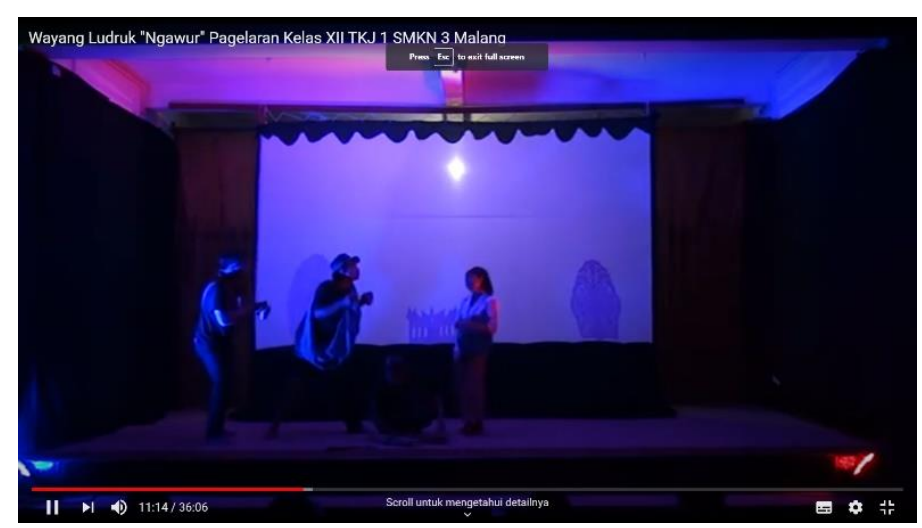

Fig 2. Wawyang Ludruk Show (source http://bit.ly/wayangludruk)

This ludruk wayang performance model is expected to be able to provide added value for improving character education for the younger generation of Indonesia, especially for students of SMKN 3 Malang through the values contained in the play or the wayang story. Moral values are important things that people aspire to and believe in to be achieved by humans to have a good and dignified personality [15].

Through the wayang development model offered and practiced by the younger generation, it is hoped that they will get good advice about the noble values that are reflected in the wayang performance model. By appreciating, analyzing, and creating wayang puppets, the younger generation will get a good image of human morality in wayang ludruk. The ludruk puppet show contains a deep meaning about the importance of ethical teachings for human life.

\section{Conclusion}

"When ludruk meets puppets: The development of a competition-based inter-class learning system in Javanese language learning at SMK Negeri 3 Malang is one of the alternatives to developing wayang and ludruk in Indonesia. This model has an impact on the growing public interest. Besides, this learning model is also an important vehicle for reviving shadow puppet 
performances from the threat of extinction. Also, this learning model has implications for strengthening the character of students by producing their traditional works of art.

Innovation The development of an inter-class competition-based learning system in Javanese language learning at SMK Negeri 3 Malang Wayang Ludruk is based on the main spirit, namely universal human values. These values are transformed into various values that are believed to be a reference for people's lives.

\section{References}

[1] V. Thersia, M. Arifuddin, and M. Misbah, "Meningkatkan Kemampuan Pemecahan Masalah Melalui Pendekatan Somatis Auditori Visual Intelektual (SAVI) dengan Model Pengajaran Langsung," Berk. Ilm. Pendidik. Fis., vol. 7, no. 1, p. 19, 2019, doi: 10.20527/bipf.v7i1.5638.

[2] T. . Rivers, “Ten Essential for Character Education," J. Gen. Educ., vol. 3, no. 53, pp. 247-260, 2016.

[3] U. S. Winataputra, "Multikulturalisme-Bhinneka Tunggal lka Dalam Perspektif Pendidikan Kewarganegaraan Sebagai Wahana Pembangunan Karakter Bangsa Indonesia,” J. Pendidik. Dan Kebud., vol. 14, pp. 1009-1027, 2008, doi: https://doi.org/10.24832/jpnk.v14i75. 364.

[4] T. Sampurno, Seni, Melukis, dan Anak Autis: Penanganan dan Pengembangan melalui Seni dan Cara Mengevaluasi Karya Anak Autis. Yogyakarta: Psikosain, 2015.

[5] L. J. Hetrick, “My Desire for Art Education,” Stud. Art Educ., vol. 54, no. 3, pp. 273-276, Apr. 2013, doi: 10.1080/00393541.2013.11518899.

[6] D. L. Shields, Character as the Aim of Education. 2015.

[7] F. Y. Sriana, T. Trisakti, and S. Yanuartuti, "Pengalaman Fenomenologis Pertunjukan Reog Ponorogo dan Relevansinya terhadap Pendidikan Karakter," Lokabasa, vol. 11, no. 1, pp. 38-49, 2020, doi: 10.17509/jlb.v11i1.25193.

[8] R. Kraus, "Transforming Spirituality in Artistic Leisure: How the Spiritual Meaning of Belly Dance Changes Over Time," J. Sci. Study Relig., vol. 53, no. 3, pp. 459-478, 2014, doi: https://doi.org/10.1111/jssr.12136.

[9] H. Read, Education Through Art. London: Faber and Faber, 1970.

[10] S. D. Darmono, Kebudayaan Populer di Sekitar Kita. Ciputat: Editum, 2009.

[11] T. Plomp, Educational Design: Introduction. From Tjeerd Plomp (eds). Educational \& Training System Design: Introduction. Design of Education and Training (in Dutch).Utrecht (the Netherlands). Lemma: Netherland.Faculty of Educational Science and Technology, University of Twente., 1997.

[12] M. Sukerta, Pande, Metode Penyusunan Karya Musik: Sebuah Alternatif. Surakarta: ISI Press Solo, 2011.

[13] Sunardi, Nuksma dan Mungguh: Konsep Dasar Estetika Pertunjukan Wayang. Surakarta: ISI Press Solo, 2013.

[14] S. Satoto, Pengkajian Drama I. Surakarta: Sebelas Maret University Press, 1989.

[15] Solichin, Falsafah Wayang Intangible Heritage of Humanity. Jakarta: Senawangi, 2011. 